DOI: $10.20472 / S S .2016 .5 .2 .005$

\title{
SOCIOLOGICAL REGARD TO CHILD MOTHERS DRAMA IN TURKEY
}

\section{GULSER OZTUNALI KAYIR}

\begin{abstract}
:
Child mothers is a global, social, socioeconomic, psychological and healty problem, created through the social and public institutions. Some concepts must be discussed in scientific context, collection of data need a special work. Child mothers married off in too young ages are exposed vital problems to girls and women. Powerty, traditional and culturel authority and sexist mentality of the sociopolitical system tied to social instutions, demand sociological attention.

In Turkey child mothers drama is a organized crime by many institutions. The reports, researches, international and national law will be the basic data for this study. Contributing within internatioal measures and actions to ensure the social change in the direction of the gender equality development and for happily married for the future generation. The causes, sociological context, consequences and suggestions will be examined in order to inprove child mothers drama in Turkey.
\end{abstract}

\section{Keywords:}

child mothers, child bride, violence against childrens, violence against women, international law, Turkey

JEL Classification: J12, J13

\section{Authors:}

GULSER OZTUNALI KAYIR, UNIVERSITY AKDENIZ, Turkey, Email: gulserkayir@akdeniz.edu.tr

\section{Citation:}

GULSER OZTUNALI KAYIR (2016). Sociological Regard to Child Mothers Drama in Turkey. International Journal of Social Sciences, Vol. V(2), pp. 73-91., 10.20472/SS.2016.5.2.005 


\section{Introduction}

Child mothers are an global and social problem and frequently forcing into marriage affects the life of very young girls in a negative way. It causes to maintain a problematical and unhealthy life from the point of physical and psychological of the young girl who doesn't choose to become a mother. The human rights of child mothers are violated; a collective and organized crime is committed by the government, family, law, education, religion, economic and political institutions; the whole life of the woman is put under encumbrance as well. Child marriage ensues the adverse outcomes that will effect the whole public health sociologically along with the attributions that include all violence types against woman such as the trade in human beings about sexual, economical, social, psychological and physical. It may cause to continue the unhealthy growing for generations, continuation to the social reproduction with traditional culture forms and life-style; and causes to arise a society that mental disorders reign over. It may give way to a social drama that deranges the health of the country sociologically, causes to the results involving death and overlooks the sexual and economical exploitation of the child by the social institutions.

\section{Methodology}

The drama of child mothers is aiming to bring into the open that is one of the violence types against woman and aiming to disclose the confidental and covertness from the point of phenomenological. Scrutinising, review and explication through indirect observation with document browsing, collected the quantitative and qualitative data, within the frame of sociological, historical materialist and critical theory. In this study, sociological frame will be drawn; scientifically concept union issue and constraints about data collection will be tried to reveal. The status of child mothers over the world and in Turkey will be revealed by deduction method. The bases of the child marriage will be presented along with different dimensions, the results will be scrutinised as well as solutions will be offered. International and national researches, agreements, reports will be resourced.

\section{Scientific Frame and Data Collecting Issues}

It's useful to discuss that the continuation of child mothers drama as an universal concern concerns the mentality changes that the sociology which concerns the social transformation closely has to address.Within this context, this subject that sociology is passing over needs to be reviewed from universal and Turkey scale.

\subsection{Sociological Frame}

The sociopolitical system that is based on the laws, justice, equality and freedom is become to fight with corruptions, environmental catastrophes; biopolitics and biopower that are based on human bodies according to the Foucault's (2015) concepts are 
appearing as a regime in Turkey. The human is a saleable, purchasable, can be impounded and killed material like merchandise as a result of having no limits, being exception, contradiction to law of the capitalism and has become to valuable resource as well. Police interventions that are happening for the last 13 years in Turkey, status frustration of the army, corruptions, unlawfulness and Gezi Park Revolt against this lawlessness, extensive strikes, lone-parent families, child mothers are some specimens of the social change.

Three main factors drive child marriage: powerty, traditional and culturel authority and sexist mentality of the sociopolitical system and social instutions. Examining on the basis of social change theory, it is useful to review the historical processes of the societies. Right of private property that bases the social stability to economical base and social value of the private property have been changed by Marxist view. The concept that bases the social stability to the authority form politically has become to request to prove whether deserves by the party that has the authority. Today, the authority issue is become widespread and the communities do not be able to stem the tide with this issue.

Reviewing the drama of child mothers from the sociological point, specifying the necessity of the socio-cultural change will be a good start. In sociology, there are different approaches regarding the social change on the basis of structural, functional, swiftness, scale factor and social relations or as a change that from the point of the norms, values and culture. Also, the family can be the object of all these approaches. As being dominance on social change that the family, parenting, sexual relationships, freedom subjects are coming to the front; it's observed that the new circumstances are emerging as a result of the changes in socio-cultural values and relationships. increasing of poverty, alienation of children from the education, lack of accessing to the adequate information; the negative development of patriarchy but awareness and struggle of women, increasing of freedom and democracy demands are a testament to the social change. It must be emphasized that the transformation has started to show evolvement with awaraness through acculturation even though the change is not in same pace and attribution in all classes of the society; governmental ideology and public policy are effective herein.

It is important to consider that diversifying characteristics can be observed in the same society even at different communities from the point of the family form and relations; solely characterising of biological and juridical criterions will be inadequate regarding the family and intimacy, privacy, the value that is given to kid by the family, variability in the relationships in parental relationship (Verité,2003:30-32). Maigne (2003) identifies the family that "All of reorganisations that are carried out to meet the children's needs in particular to three levels as: physical, emotive and psychic life to ensure grown-ups being family; Martin (2003) indicates that the family subject is becoming controversial; Delecourt (2003) who indicates the family that just not should be considered within the context of it's role, function, position; the emphasizes that the cultural, economical, social and political contexts have to be taken into consideration in the parenting as well. The 
main actor as function, position and socioeconomic and political basics on child mothers issue; is the state.

From the point of comprehend to social change, I wanted to point out about the consideration of child mothers as a public issue, and important mission and responsibilites are fallen to the state and social institutions.

\section{Table 1 : Assessment of Socio-Cultural Change Condition from the point of Child} Mothers and Social Institutions

\begin{tabular}{|c|c|c|}
\hline $\begin{array}{l}\text { Anticipated Socio-Cultural } \\
\text { Conditions }\end{array}$ & $\begin{array}{l}\text { Circumstances that will be able to } \\
\text { ensure life changes of Child mothers }\end{array}$ & $\begin{array}{l}\text { Relevant Socia } \\
\text { Institutions that } \\
\text { will provide the } \\
\text { social change }\end{array}$ \\
\hline $\begin{array}{l}\text { Emerging needs usually } \\
\text { require new } \\
\text { circumstances that are }\end{array}$ & $\begin{array}{l}\text { Preventing on the whole increase the } \\
\text { amount of poor family in the country, } \\
\text { ensuring the equilibrium about }\end{array}$ & $\begin{array}{c}\text { State and } \\
\text { Government, } \\
\text { Economy, }\end{array}$ \\
\hline leading to change. & $\begin{array}{l}\text { income distribution, supervision of } \\
\text { the obligatory education, } \\
\text { arrangement of the privacy and } \\
\text { human rights, elimination of the legal } \\
\text { obstacles, taking on informative and } \\
\text { restorative task by media regarding } \\
\text { this issue. }\end{array}$ & $\begin{array}{c}\text { Education, Law, } \\
\text { Family, Health, } \\
\text { Media, Local } \\
\text { Authorities }\end{array}$ \\
\hline $\begin{array}{l}\text { The requirements are } \\
\text { associated with the } \\
\text { readiness for change. }\end{array}$ & $\begin{array}{l}\text { Meeting the basic needs of the } \\
\text { children and family, giving } \\
\text { government support to family which } \\
\text { are struggling with economic } \\
\text { problems as being financial, } \\
\text { psychological, cultural to prepare for } \\
\text { change }\end{array}$ & $\begin{array}{l}\text { State and } \\
\text { Government, } \\
\text { Economy, } \\
\text { Education, } \\
\text { Social Welfare, } \\
\text { Local } \\
\text { Authorities, } \\
\text { Health, Religion }\end{array}$ \\
\hline $\begin{array}{c}\text { Knowledge is an essential } \\
\text { provision for change as } \\
\text { well }\end{array}$ & $\begin{array}{l}\text { Enabling the knowledge of the family } \\
\text { regarding the child development and } \\
\text { health, enlighting about child rights, } \\
\text { including into curriculum. }\end{array}$ & $\begin{array}{l}\text { State and } \\
\text { Government, } \\
\text { Economy, } \\
\text { Education, Law, } \\
\text { Family, Health, } \\
\text { Media, }\end{array}$ \\
\hline $\begin{array}{c}\text { The type of dominance } \\
\text { values that are existing in } \\
\text { a culture and the } \\
\text { qualification and general } \\
\text { attitude of persons }\end{array}$ & $\begin{array}{l}\text { Preventing the accultration of the } \\
\text { family which stipulates that bodies } \\
\text { and sexuality of the girls should be } \\
\text { taken under control of man, } \\
\text { according to the existing dominance }\end{array}$ & $\begin{array}{l}\text { Education, } \\
\text { Culture, } \\
\text { Religion, } \\
\text { Health, Law, } \\
\text { Media }\end{array}$ \\
\hline
\end{tabular}




\begin{tabular}{|c|c|c|}
\hline $\begin{array}{c}\text { an important provision for } \\
\text { the change. }\end{array}$ & $\begin{array}{c}\text { and patriarchal mentality } \\
\text { change,reproductive health, family } \\
\text { planning becoming to be a part of the } \\
\text { education. }\end{array}$ & \\
\hline $\begin{array}{c}\text { Complexity of the } \\
\text { Socio-Cultural Structure } \\
\text { is an essential provision } \\
\text { for change }\end{array}$ & $\begin{array}{l}\text { Ensuring the change of cultural } \\
\text { stereotypes and traditional values } \\
\text { that are not more complex, creating } \\
\text { the conditions for social gender } \\
\text { equality, becoming to be a part of the } \\
\text { education, shouldering the positive } \\
\text { functions by the media. }\end{array}$ & $\begin{array}{c}\text { State and } \\
\text { Government, } \\
\text { Culture, } \\
\text { Education, Law, } \\
\text { Communication }\end{array}$ \\
\hline
\end{tabular}

Fichter J. (1996), It is adapted originated from the book What is Sociology? Translator. Nilgün Çelebi.(2007) Publishing Anı Yayıncılık Ankara.

Child marriage is a social problem as shown in Table 1, the main bases of the status change of the child mothers in a sociological context, are ensuring the massive changes on the social institutions related with mentality of the government, economical policies, education, health, law, and need to correcting of the following drawbacks:

a) State and Government: Defaulting the obligations of protection, economical development, best interest of child, welfare and happiness of the child, observing and supervision by the government, impunity,

b) Law: Violating the legislations by legal institutions and enforcement unit, encouraging for child marriage, unquel changes against child rights,

c) Family: Defaulting the duties and responsibilities about protection and lookout by the family, perception of child marriages as normal

d) Religion: Giving permission for child marriage by institution of religion's staff and making it legal,

e) Education: Nonintervention by educational institution in spite of being school age,

f) Culture: Having a patriarchal and sexist point of view towards to woman, failure to change the effectiveness of socio-cultural streotype through education,

g) Media: Encouraging attitude which are becoming to be aggravating factors of the drama of child mothers.

The child marriage as an collective organized crime in Turkey continuing and the results are quite severe for women and childrens. As being unlawful, in defiance of the laws and of the state, by violating the human rights, by the marriages in child age, it's necessary to interfere against to the continuation of the delinquency of the social institutions such as government, law,economy, family, religion, education, health, culture, media, local authorities etc.

Paying our attention to Elkind (2001) who warns "Concentrating on the cultural variables that break up the integrated sentiments of the concept of children is the best...Propounding a new education and parenting strategy, the needs of child-neither parent's nor teacher's- have to be a starting point everytime" will be on the right lines. In 
addition, the statement of Badinter (1992) as "The death of patriarchy is the result of a dual upheaval: First, the father lost his respectability, second, Eve changed the rules of the game. 18th and 19th centuries had divested father from his holy groomsman which takes him under it's protection. Also, 20th century has taken away the economic power monopoly with its moral authority" is important to comprehend the transformation of patriarchal family through historical look.

This statements that are expressing that the social change improves from patriarchy and gender; are entailing to look from the childe way and critical from scientific and social point. It is basis of the need for socio-cultural change from the point of child mothers. This strides that destroy the male power have brought the strong violence to woman. While revealing the women who can take control the fertility and their bodies; even has brought to increase violence that is arised from male dominance, the struggle of women for freedom and equality.

Giddens (1994) has studied about "transformation of privacy"; developed the theory of democratisation of politics and social institutions through the democratisation of private life and sexuality. Transformation of privacy has a qualification that provides the change of social institutions, bringing the social change and transformation of public institutions in order to protect children and women. Within the context of body, individual identity and social norms, this new sociological support can bring social change, the transformation of the public mentality to protect child mothers and women by the equipped institutions.

\subsection{The Issue of Conceptual Union and Data Collection}

The family, privacy, sexual relationship, family form are changing along with social change as well, it affects the literature, using some concepts related with the childhood as if in the same content is being witnessed. Inconsistency and contradiction in terms that appears in international literature as well as law texts is persisting.

Child Bride concept frequently used in Turkey is deceptive. Because, being a bride expresses the way that is chosen by women in order to reach to the happiness, the fictionalised life-style. However, the concepts of child and bride are submitted as a source of happiness encountered in playing age; encouraged and legitimated. It's a fallaciousness indication from the point of scientific as well as child development. The decision about marriage is made by the family or others. Disregarding the physical, mental, bodily, sexual and personalistic development processes, objectifying and instrumentalisation the child, existence of sexual exploitation, illegalisation, the informal imam marriages can be occured. Early marriage should not be used, because the ages of 22-24 are deemed early for the marriage in our day in modern Turkey. The child marriage concept can be used in order to reveal the child victims in juridical texts from the point of emphasizing to the age criterion, existencing the force and absence of free choice, revealing the action that is making by others. 
Even though, conceptualisation issues are in the lead; there are some shortcomings in the international texts regarding the data collection and issues are existing from the point of the government's attitude. It has been seen that the indicators of death rate, nutrition, vaccine, education are contented when the child comes in the literature. U.N. and UNICEF and Turkish documents must take in the consideration the quantities of child mothers deaths and her babies who are passed away and age limit below 13 as criterion in their researches. The marriages of the children who are in 9-15 ages are not kept in Turkey.

The quantity of social survey studies is less in Turkey, regarding the exploitation and negligence in child age; there is no defined and official data concerning to the frequency and dispersion of the exploitation and negligence (Zoroğlu and al.2001:69-76). By the acceptance of the child marriage as being an exploitation, harassment and violence, ensuring to take place in data related with violence will stregthen the efforts for violence prevention. The presence of evidence in poverty data that how much income has been allocated for child in household has importance regarding the struggle with child mothers issue.

\section{The Situation of Child mothers in the World and in Turkey}

Report of The Status of Children in the World shown us; the rate of child mothers is too high in some countries within the criterions of birth, death, health, education, protection. With the highest rate that $29 \%$ of children who are below in 15 are still getting married $33 \%$ in Bangladesh and $62 \%$ in Chad and the increase the family violence as well (UNICEF,2014) "Every day, 39,000 girls become child brides or about 140 million in a decade" (UNFPA,2014a). Every year, 2 millions of girls who are below 15, constitute the new mother of total 7,3 millions which are joining into the world population. In the case of the continuation of this situation; the birth rate of the girls who are below 15 will be able to reach 3 millions in 2030 (UNFPA,2014a). Joining millions of unhappy children and women into the population is coming to mean the health problems of child mothers, lack of education, inability to work and gloom of the future life.

It has been seen that there is human rights violation of the girls and special measures for child mothers is forgotten in Turkey. $33 \%$ of women in countryside, $26 \%$ in the cities are getting married under 18 and this rate is increased up to $39 \%$ in Southeastern Anatolia Region (Turkish Family and Social Politics Ministry Research,2011).

Turkish Assembly handle the subject as early marriage, indicates that there is direct proportional between frequency of early marriage of the children and poverty of the family, consent from the point of the religion, equation, publicity, the rules of banns and registration are provided by civil marriage, ensuring the necessity to fulfill the responsibilities adequately by headman and religious official (Grand National Assembly Commission Report,2009). "Child marriages are the result of domestic violence as well 
as family violence. Child marriage restricts the abilities, communication opportunities and knowledge of girls and hinders the socialising, decrease their locomotion, constitute an impediment against their own decisions, restricts their actualization, destroys their self-confidence. These are unnatural results of the marriage...Child marriages have a connection with domestic sexual abuse. In large households, girls are getting married in order to avoid harassment by their close relatives then are moved away from their home. There are harassment risk of her spouse's father or brother in the house that she moved. Because, "bride" is still child, therefore she is defenseless and helpless" (Grand National Assembly Official Records,09.03.2015).

University Hacettepe Survey (2014) reveal that the families which are in low socialeconomic level are forcing the girls in ten ages to marry with the men who are in 40's, 50's and 60's in exchange for one thousand or two thousand dollars at Southeastern Anatolia and many parts of country. The researches are revealing that one out of every three married women, is being child marriage today. The marriage age for girls is reduced till 12 in Turkey (Çakmak,2009). Turkey has ranked number two regarding the child marriages in Europe (UNFPA (2014b).

In Diyarbakır that has highest rate of child marriage. $12 \%$ of children married in child age are literate, $45.7 \%$ of the children are married in exchange for brideprice; the girls of $72 \%$ who are in married without their consent; more than $30 \%$ never saw their spouses; $75 \%$ of this girls have no right to speak for the decision that are made at home; near to $20 \%$ of this girls are getting married before the menstruating; more than half of the women are getting married before turning; and there is 181.000 child bride across the country according to the report and indicates that the rights of girls are disregarded in Southeastern Anatolia, so they undergo by sexual abuse (University Dicle and Diyarbakır Municipality, 2012).

Determining the nonexistence of pure juridical system particular to children in Turkey, no formation of organizational structure, nonexistence of data collection system including all children and absence of a unit that directly in charge with this issue, by National Child Rights Strategy and Action Plan for 2013-2017 (Turkey Official Gazette,14.12.2013) reveal that the development, legal rights and protection of children are not yet be able to ensure in Turkey.

\section{Bases of Child Mothers Drama in Turkey}

It has been observed that the child mothers drama is based on historical, cultural, economical, religious, juridical and social origins in Turkey. We confront with paternalistic mentality and family structure based on male-domination, traditional cultural codes, stereotypes, because of the social gender inequality sentencing the woman into secondary status, taking away the right of fertility and sexuality. The rate of child mothers are high usually in patriarchal families that are economically weak, in low education level or even they don't have literacy either. Considering the women and bodies as a sexual 
object, instrumentalisation, selling like a merchandise, a matter of honour, virginity check, neighborhood pressure, sexual abuses, incest, extramarital pregnancies are the main factors of child marriages for girls. In addition to this, getting married of girls to their raper, the situations such as escape or abduction are revealing the child mothers as well. The quantity of married girls who are under 18, just registred is 40.428 girls, for boys the number is 1.903 in 2012 (Bursa Bar Association, 2012).

\subsection{Violence Against Women and Children}

The drama of child mothers is resultant of the violence that is exposed by women and children. Johan Galtung (1969:167-191) makes reference to 3 types of violences that interact with one another as direct violence, cultural violence and structural violence.

"Direct Violence", is a physical violence that occurs through inactive harassment or power assertion that is performed by a person. "Structural Violence" is an appearing form of the violence that occurs from inequality of opportunity and using inequivalent force that is a part of social structure. Galtung defines the "Cultural Violence" based on cultural characteristics as the legitimating way to structural violence as a preventable infringement that is caused to meet the humanitarian needs in a level that is less than the possible potentially. Child marriage contains above mentioned three violences. Bereaving of education, development opportunities of girls causes to structural violence; committing by the social institutions such as family, imam, judge, educationist, law is setting a precedent for cultural violence; child mothers means sexual abuse and rape, should be considered in direct violence. Gender, socio-cultural structure that are based on patrilineal system and violence in mutual interaction and it becomes institutionalized and legalised in the culture of the society along with its structural characteristics that are creating the disparities based on gender. In the case of Turkey event also; "honour" concept that makes to continue the gender disparities is one of the main base of the culture. And "abduction of girl", " wedding ceremony"," forcing into marriage" or "honour killing" are appearing as the institutionalized specimens of the structural violence.

It reveals that the women are got married off in different ways in child age without their free choices, without their consent and the marriages such as Bride Exchange, Child Marriage, Blood Money Marriage, Second Wife Marriage, Consanguineous Marriage which are containing all kind as direct, structural and cultural vioelences against women and violate the rights of childe and free choices of the women are reported in parliament (Grand National Assembly Survey,2011) Marriages where there is no free choice are violence indicator.

Flying Broom Association (2012) take attention to the violence "Marrying children means accomplice to rape, legitimizing rights violence and perpetuating gender inequalities" has the first women association who conducted to combat child marriages in Turkey since 2006, has a documentary, Child Brides Campagne and related project contuining.

The male dominance against women on daily life, at law, in religion, in language, in economy, at public and private space is one of the cultural violence forms that resultant with child marriage. The most important way of cultural violence is preventing to perceive 
the direct violence and structural disparities as being a violence; in other words; legitimating it (Kurtoğlu,2009).

Increasing the lack of confidence to men, harassment and exploitation in the community are frightening the families, accelerating the decision about giving in marriage of their girls as soon as possible, the controlling of girl will be transferred to the husband from father; in a manner of speaking, the family will relax, the honour charge will be transferred as well. Due to this, married girls may escape from home, may forced to be prostitution and may subject to international woman trafficking (Grand National Assembly of Turkey Official Report, 09.03.2015). The vioelence against women and children is an importent factor to increase the number of child mothers.

"Women who married at younger ages were more likely to believe that it is sometimes acceptable for a husband to beat his wife and were more likely to experience domestic violence themselves" (UNICEF,2005).

\subsection{Socio-Cultural and Psychological Bases}

The studies about developmental psychology during the recent years remark that though the identity development begins in puberty; it becomes to intensify in the transition years to adulthood.

Childhood is a period that the physical, mental and psychological development of the person is carried out. New approaches are in a nature that the children should be considered as different with their interests, needs and expectations instead of comparision with adults; it should be accepted as being social actors that have abilities to build social reality and construal. Like femininity, through interdisciplinary and holistic outlooks, the childhood also needs to be discussed by multi-realities and critical method due to the changes in intercommunal and cross-cultural or same socio-cultural structure. Therefore, the child mothers issue has become to be social norm in the country and urban commonly along with traditional thoughts and life styles in Turkey. For this reason, it is required to consider as an economic and socio-cultural based problematique. In this regard, the origins of the child mothers are social gender inequality and viewpoints against to woman who has socio-cultural quality.

Ambition for male child in Turkey is the result of traditional and paternalistic mentality and can be seen as a common idea in the families who are in countryside and urban both. Commonly, having no male child is considered the woman's fault as opposed to the truth about the determination of gender by male and the woman is being denigrated. To not giving birth male child by the child mothers, causes to be subjected to violence her substantially.

The mentality about the ensuring to protect the girls against sexual abuse, rape or extramarital affair by childe marriage, symbolising the honour of family in Turkey. 
Traditional mentality that supports the girls have to stay by the side of their husband, is becoming strong by the cults that are supporting the erewhile marriage. Legitimisation ways of child marriage are performed by the engagement or wedding ceremonies that take several days and rituals. This agreement has a function to hide and legitimate the child marriage and socio-cultural covertness by the committing of social and institutional solidarity.

Even the rates of child mothers are known in Turkey as well as in the world; it is possible to express that their situation is unknown. It may possible to express that the families can choice the child marriage in order to protect themselves and girls, to protect their premises and to keep their status quo. Furthermore, within the frame of religional, cultural and traditional attitudes, child marriage is normalized by the practices such as "bride price"; and it should be noted that ensuring to gain illegal economic profit through this way. Female circumcision, early marriage, girl murder, honour killing and early pregnancy can be given as sample as in terme of U.N. "Detrimental Traditional Practices" (1995).

With aggravated circumstances of the marriage, domestic labor, care for whole family, education and health of children, so women sacrifices her life for the prosperity, peace and health of all family members, even including spouse's father, mother and his close relatives; keeps her life by obeying and under discipline. Being a child does not rescue her from this obligations and it means best interest of child ignored.

\subsection{Economical Bases}

Male dominance and patriarchy are a widespread social nature on the world along with the capitalism that is an exploitation tool of women's domectic labour and forming the basis of capitalist societies.

The main bases of child marriages are poverty and poor trained families. The is related with the income distribution throughout the country and experiences in Turkey in recent years intensively. In accordance to the calculation based on calorie requirement that needs for a family to be able to live healthy, the hunger limit of a family of four persons has increased 1.121 to 1.238 Turkish Liras in 2014; the poverty level has increased to 4.054 in 2014, from 3544 Turkish Liras in 2013 (DISK-AR,2013). The average individual quantity of the family is 3.59 in Turkey and $93 \%$ of the population remains under the poverty level, only 7\% earns around USD 1000 or above. The poverty level in children under 15 at rural regions is $50,15 \%$ in 2009, yet this level is around $4 \%$ in Sweden and the poverty for children under 15 has increased and the child poverty at rural regions is reached at dangerous level; Turkey has highest child poverty rate within the OECD countries at 24.6 percent, which is almost twice the OECD average (UNICEF Turkey, 2012a; 2012b). 
The poverty in Turkey is emerging as one of the main factors of force into child marriage. Families can sell their own girls in exchange for thousand or two thousand dollars or a few cattle to the men who are in 50's and 60's. Early marriages are causing to drop out before maturation and started to work as housewife; subjected to family violence and it reinforves the poverty cycle according to the relevant UNICEF reports.

The poverty level in country-wide is higher 11 percent from the assumed, when we evalue through the measurement of the poverty of time and consumption by a new approach : In Turkey 7.6 million secret poor persons have been determined that are not reflected in the calculations (Masterson,Zacharias,2014:24-26).

\subsection{From Children's Health To Social Health}

However, when we say child health, we make reference to "well-being" document (UNICEF-Turkey,2012a) identifies as "Performing the idiocratical potential related with itself of individual, others and associated with the environment through physical, emotional, mental and spritual development by the individual". Health and well being of child means that child takes priority on the side of national policies. Child marriage means girls drops out, keeps away from education and failure to reach to mental, sexual maturity and physical development and deterioration of well-being. The possibility of sexual abuse at wedding night is high, she has to obey against family discipline. On the other hand, when being mother is added, mother and child are under the risk of disease and beyond to the all issues that can be continued whole life, the death comes for both. The mortality risk for children whose mothers are under 18 is $60 \%$ more (Flying Broom,2012).

According to the study (Santhya et al 2010:132-138) related with the comparision of women who are got married before 18 and after, the women who got married at late are experiencing more positive developments from the point of the organizing their life, being glad, fertility health and not exposed to sexual, physical violence. In Turkey, increase of poor families, lack of educational level are causing to remain the women and children defenceless. Failure to meet the required needs of children that would ensure the healthy development of children in term of physical, physological and mental, is caused to shoulder the improbable identities by the child who is in play age, then social health is deteriorated deeply. In other words, it means never happened childhood, happinesses, annihilation of maiden dreams with respect to love, whole life of women is captured.

One out of every three women is making child marriage and the marriage age is reducing till 12 for girl (University Hacettepe Survey,2008) 10\% of all births in the world are subject to the girls who are between the ages of 15-19 according to reports (WHO,2006). 
Predisposition to the sexual diseases are increasing and the death risk for the pregnancies that are subject to the girl under 15 is more than 5 times comparing to midtwenties (Boran et al, 2013:58-62) b Even, it is possible to consider under high risk category (University Hacettepe Survey, 2013).

The suicide of children below 18 in Turkey quantity was 95 in 2000; it has increased to 107 in 2010 (Grand National Assembly Official Records,09.03.2015). And, for Turkish Statistical Institute (Turkish Statistical Institute,2013) suicide of children was 274 in 2002 , increased to 330 in 2012 . While the Proportion of children committing suicide in total for under 18 years old is $23 \%$ in 2011, over than 18.7 in 2002 for the girls (Turkish Statistical Institute, 2014).

The condition of women who are subjected to violence has been revelaed by Burgess and Holmstrom (1974:981-986) scientifically as "trauma syndrome" and as a common feature of women who are subjected to rape in a child marriage.

\section{From the Stand Point of Law}

International Treaties, Convention on the Rights of the Child and international law says one thing and the state makes different applications. Children and women pays the results of this political contradictions.

\subsection{International Level}

Convention on the Rights of Child (1990) Defaulting of Turkey has been revealed by the researches, because Turkish government giving priority to the family, but government is in charge of best interest of child.

The guidelines relation to child friendly justice (2010) Should be considered as an main document that calls the states and social institutions for the duty and obligations.

Lanzarote Convention (2010) signed in Spain in 2007, in the World in 2010. It has been come into force in Turkey in 2012, aims to prevent the sexual abuse and exploitation against children, to protect child victim of sexual crime, to ensure the justice for children and to impose criminal proceeding for wrongdoers.

CEDAW (1981) Turkey has signed in 1985, has removed the reservations in 1999. However, most of the articles of convention are not met requirements. Forced marriage, early engagement or child-marriage, discrimination, sexism continue and are conflicting with most of the articles of convention, defaults regarding the relavant obligations.

Istanbul Convention (2011) Entered into force in Turkey in 2012. Even specifies that the early marriage is violence against women, sufficient and efficient required 
precautions have not been taken in Turkey yet and the encumbrances about child marriage have been removed and it is incongruet to the convention.

Assuming the child marriage, child motherhood as organized crimes fm obstruction of law enforcement by family or/and other social institutions, required hight harsh penalty and sanctions in Turkey. When reviewing above mentioned documents, it has been seen that inludes child marriage and child-mothhers also. In the case of ensuring the changes, from the point of the children which are got sexual attacked 5 of them in the world and the future of our country's children, being in harmony with other agreements, recognition as crime and sexual abuse of child marrige, preventing the exploitation may make great contributions in order to protect children.

\subsection{From the Point of National Law}

"The state takes required precautions in order to ensure the peace and prosperity and particularly to protect mother and children..." say the Turkish Constitution (1982) Law accepts the family as basis of the society; specifies that the state has to take required precautions in order to ensure the welfare and peace of family particularly, to protect mother and children. Albeit the serious efforts of women's institutions and lawyers in Turkey, child marriage has not yet ceased to be a problem. In practice, a prohibition is cancelled regarding the forced marriag and the inceasing of children's age is carried out by juridical institution. Marriage Regulation (Official Journal, 10.02.2015) has been amended again; kerchiefed photo of woman is become to be acceptable. The most important amendment that should be done is related with the age as for the clause that for majors without permission, if turns 17 by the permission of parent, turns 16 can be get married by the permission of the judge is keeped as it was. It reveals that the government is insisting on the defaulting about the protection of children and prevention of child marriages and this amendment has been done consciously in order to bring shariah system. Social change in the opposite direction can be the condemnation of childrens and women. Also noted by UNFPA (2014a) "common definition of a child as a person under the age of 18 does not exist in Turkey's laws".

Many babies have no birth certificate, registration is on her mother or spouse's family and even mostly registration is not carried out, civil rights are taken away, the rights of childrens and child mothers have been violated. Following from the decision of the Turkey Supreme Court (2013) "In the lawsuit that correction request of mother name of the child due to the fact that the child is registered in favour of another mother, will not be able to decide without DNA test even the existence of report of birth and witness statement" is one of the effective and exemplary decision accordingly.

By the recent decision dated 27.5.2015 of the Constitutional Court, the clauses of 5 and 6 of Art. 230. of Turkish Criminal Law, have been cancelled, with the removing of civil marriage stipulation enable to solemnize religious marriage priorly, principle of Child's 
Best Interest is transgressed as well as child marrige is now legalized (Turkey Official Gazette, 10.06.2015). So, girls will be able to get married with religious rituals and she will lose her "official assurance" in the event of marriage or divorcement. A rape that is made by a person in 70 against a girl in 12 years old, will be legalized, the obstacle will be removed from the front of child marriage.

This deep trouble is unlawful and even though carrying out by Constitutional Court in despite of negative votes, are revealing that the judgement as well as children are become an ideological tool of the government. The serious researches regarding the child marriage to remove as from being a socio-cultural-economical issue that were done by women's institutions have been disregarded. In order to annul this decision, a new struggles has been initiated.

Union of Turkish Bar Associations (2014) has revealed that the quantity of applicant to the court in order to give in marriage for their girls that are under 18 is increased in the rate of $94.2 \%$ in 2012 comparing 2011 , and they refuse the concept of child bride. Appropximately 20 thousands of families litigated in 2012 in order to get marriage permission from the courts (Grand National Assembly Official Records,19.02.2015). These are revealing the serious course of drama of child mothers.

Even if we assume that there is no compulsion about child marriage, it means that is violation of human, sexuality and fertility rights of women and preventing the free decision of the individual regarding her body and future.

"Incuding the sexual expolitation, violence and exploitation against children along with child marriages continue to be a major problem...A more extensive strategy regarding early detection of children who are under risk and for preventing, child welfare is required.... In despite of remarkable improvement during the last ten years in Turkey, cutting the poverty in half, gender equality and environmental protection goals may not be able to be achieved as of 2015"(Turkish Prime Ministry,2010). Regrettably, it has been seen that the prediction of UNICEF (2012b) is true.

\section{Conclusion}

In order to support child mothers we need an global, juridical and sociological methods. Examination of the social change, conceptual union, standardization of data collection, commencing from very small ages with interdisciplinar principles, in order to ensure the social change in the direction of the gender equality development and for happily married fort he future generation.

Including the child marriage criterion into the Development of Women's Human Rights Goals will provide an important contribution within internatioal criterion and will give acceleration in order to achieve the development objectives . 
Defaulting the International conventions and requirements for national law in Turkey have been revelaed by the researches. In despite of revealing the necessity of justice particular to children, yet the conceptional disorder is continue and supremacy of law is discounted. It's urgent to include articles about "chid bride" and/or " forced marriage" into the legal system and new regulations about child friendly justice has to be brought. Even though, Republic of Turkey has signed the international conventions and implemented; has not taken the required and effective precautions in order to prevent the victimisation of girls due to the child marriage, has not performed its duties and responsibilities to prevent the legalisation and continuation of this socio-cultural-economical issue. Unfortunately, harmful traditional practices that will caused to the negative results from the point of women are continued with legal amendments. Child trade should be included into human trafficking and children must be protected from their families as well, for the application of the principle of Child's Best Interest and for the diagnose irresponsability of the family.

Preventing the continuation of child marriage as an collective organized crime in Turkey is primarily a one of the first responsability of Turkish government. Due to the reasons such as effect of the family to the person who will be got married in patriarchal and traditional family structured regions, upbringing, economical and psychological dependency to the family, exclusion fear; child marriage is becoming a collective complicity that many institutions are involved. While it is a crime that committed with the cooperation of social institutions that are different from the point of family, woman and children unlike that stated the international conventions, annuling the penal sanctions by Constitutional Court will make ending the drama of child mothers more difficult. Child marriage can be considered as one of the sexual violence tools then inluded into "penalty of sexual exploitation" concept. Bride exchange and bride price should be deemed as crime.

Even as child marriage should be considered as violence against children and women, other concerns like honour of family takes predence over of the violence against child for lawyers. As for that ceasing the child marriages, making the education compulsory, changing the mentalities, increasing the social status of women and informing the birth control, taking the child mothers under special protection are taking part in many articles of international conventions.

Corporate data does not coinciding with the facts of life and child marriage is gradually increasing. The urgency of the precautions like ensuring the allocate an adequate allowance from the budget for the services for children, establishing a notification and complaint mechanism that can be reachable by children, advice and assistance centers must work as a urgent counseling services, playing an active role of the human rights commissions in urbans in the notification of unofficial marriages to the competent authorities. 
Action for Adolescent Girls UNFPA /UNICEF Joint Programme (2014) can be addopted in Turkey also for investing in girls and communities and building the health, social and economic assets of adolescent girls, especially those at risk of child marriage. Solutions to End Child Marriage (International Center for Research on Women,2011) and Guidelines of the Council of Europe (2011) on child-friendly justice; can help Turkish government, has to develop special measures in order to implement its obligation for child mothers in Turkey.

Child mothers issue is a social and international human problem that prevent to use the human rights, decrease the status of women and revoke the fundamental rights notably education and even Turkey has aimed the social gender equality although there are still a defect accordingly; an efficient and extensive struggles are required.

\section{References}

BADINTER, E., (1992) Biri Ötekidir, Translator ġ. Tekeli, Alfa Yayınları, Ġstanbul.

BORAN P.,Gökçay G.,Devecioğlu E.,Eren T., "Childe Brides”, Marmara Medical Journal 2013; 26:58-62 DOI:10.5472/MMJ.2013. 02751.1.

BURGESS, A. W., Holmstrom, L. "Rape Trauma Syndrome", American Journal of Psychiatry 131 (1974): 981-986.

BURSA BAR ASSOCGATǴON (2012), Child Protection Information Sheets, www.bursabarosu.org.tr/haberler.php?kimlik.

CONVENTION DE LANZAROTE (2010) Conseil de l'Europe sur la protection des enfants contre l'exploitation et les abus sexuels, T-ES(2014)01 bil REV, 4 April 2014.

COUNCIL OF EUROPE ( 2011 ), Guidelines of the Committee of Ministers of child-friendly justice, www.coe.int/childejustice.

COUNCIL OF EUROPE (2010) Lanzarote Convention, www.coe.int/t/dghl/standardsetting/children/Lanzarote_convention_en.asp

COUNCIL OF EUROPE (2011), Istanbul Convention on preventing and combating violence against women and domestic violence, www.conventions.coe.int/Treaty/EN/Treaties/Html/210.htm

COUNCIL OF EUROPE COMMITTEE OF MINISTERS (2010) Guidelines on child friendly justice, Guidelines and Explanatory memorandum - version edited 31 May 2011, www.coe.int/t/dghl/standardsetting/childjustice/Guidelinesonchild-

ÇAKMAK D. (2009), Çocuk Gelinler (Child Brides) in Turkey www.umut.org.tr/upload/document/document_diren\%20cakmak.doc.

DELECOURT D.,( 2003), Approche thématique: rubrique parentalité, www.cyes.info/themes/parentalité/parentalité_presentation.php

DISK-AR (Confederation of Progressive Trade Unions of Turkey Research Journal) October 2013 and February 2014,www.disk.org.tr.

ELKIND, D. (2001). We hurried child: Growing up too fast, Cambridge, MA: Perseus Publishing.

FICHTER J. (1996), What is Sociology? Translator Nilgün Çelebi.(2007) Publisher Anı Yayıncılık Ankara.

FLYING BROOM WOMEN'S COMMUNICATION AND RESEARCH ASSOCIATION (2012) Çocuk Gelinler, (Childe Brides), Printer Mattek Matbaa, Ankara. 
FOUCAULT M. (2015), The History of Sexuality, Translator Hülya Uğur Tanrı̈ver Ayrıntı, Istanbul.

GALTUNG, J.. (1969) “Violence, Peace and Peace Research" Journal of Peace Research, vol. 6, no. 3, pp. 167-191. http://dx.doi.org/10.1177/002234336900600301

GIDDENS, A., (1994), Mahremiyetin DönüĢümü (Transformation of Privacy), Translator. A. Bora, ǴletiĢim Yayınları, Ġstanbul.

GRAND NATIONAL ASSEMBLY OF TURKEY, Commission Report (2009) Erken Evililikler (Early Marriage) Research Commission Report, www.tbmm. gov.tr/komisyon/kefe/docs/komisyon_rapor.pdf 13.05.2009.

GRAND NATIONAL ASSEMBLY OF TURKEY (2011) Türkiye'de Aile Yapısı AraĢtırması (Survey on Family Structure in Turkey, www.cocukhaklariizleme.org/wp-content/uploads/turkiyenin-aileyapisi-arastirmasi-20111.pdf.

GRAND NATIONAL ASSEMBLY OF TURKEY, Official Report, (09.03.2015), www.tbmm.gov.tr/tutanak/donem24/yil5/ham/b07201h.htm.

GRAND NATIONAL ASSEMBLY OF TURKEY, Official Records (09.03.2015), www.tbmm.gov.tr/tutanak/donem24/yil5/ham/b07201h.htm.

GRAND NATIONAL ASSEMBLY OF TURKEY, Official Records,(19.02.2015). www.tbmm.gov.tr/tutanak/donem24

INTERNATIONAL CENTER FOR RESEARCH ON WOMEN (2011) Solutions to End Child Marriage, www.icrw.org/childmarriage.

KURTOĞLU, A. (2009) Erkek Egemenliği, Kültürel giiddet ve Hukuk (hegemony of men, cultural violence and law), Toplum ve Bilim, (Society and Science Reveiw), No. 114.

MAIGNE, E. (2003), « Approche thématique : rubrique parentalité », www.cyes.info/themes/parentalité/parentalité.

MARTIN, C. (2003), Rapport pour le Haut Conseil de la population et de la famille, La parentalité en questions, Perspectives sociologiques.

MASTERSON T.,ZACHARǴAS, M. E., (2014), Kültür ve Siyasette Feminist YaklaĢımlar (New perspective to powerty in Turkey), Ajit, No.23, June 2014, www.keig.org/content/kitapOnerisi/FY23_41.pdf.

SANTHYA, K.G., RAM,U., ACHARYA, R., and al. (2010), "Associations Sexual and Reproductive Health 36(3): 132-139.

TURKEY SUPREME COURT 18th. Law Office (2013), Decision No : 2013/2693.

TURKEY OFFICIAL GAZETTE No. 29382 dated 10.06.2015, www.resmigazete.gov.tr/eskiler/2015/06/20150610.htm

TURKEY OFFICIAL GAZETTE No.28851 and dated 14.12.2013. Turkish National Child Rights Strategy and Action Plan for 2013-2017, www.resmigazete.gov.tr/eskiler/2013/12/20131214.htm.

TURKEY OFFICIAL GAZETTE, No. 29263 dated 10.2.2015 Marriage Regulation Amendment, www.resmigazete.gov.tr/main.aspx?.

TURKISH CONSTITUTION (1982) Art. 41, Supplement no.5982/4. 7.5.2010.

TURKISH FAMILY AND SOCIAL POLITICS MINISTRY, (2011), Turkey Family Structure Research, Ankara.

TURKISH PRIME MINISTRY, Child Protection Agency General Directorate,(2010) Research on Child Abuse and Domestic Violence in Turkey, (whith collaboration of UNICEF).

TURKISH STATISTICAL INSTITUTE (2013), Statistics on Child, www.turkstat.gov.tr, Ankara. 
TURKISH STATISTICAL INSTITUTE (2014), Statistics on Child, www.turkstat.gov.tr, Ankara.

U.N. (1990), Convention on the Rights of Child.

U.N. Office of the High Commissioner for Human Rights (OHCHR), Fact Sheet No. 23, Harmful Traditional Practices Affecting the Health of Women and Children, August 1995.

U.N., CEDAW, The Convention on the Elimination of All Forms of Discrimination against Women, (1981), www.un.org/womenwatch/daw/cedaw/cedaw.htm

UNFPA- Turkey (2014a) Child Marriage in Turkey (Overview), June 2014, Version 2, eeca.unfpa.org/sites/default/files/pub-pdf/unfpa-turkey-overview.pdf

UNFPA (2014a) The Power of The 1.8 billion, State of World Population 2014.

UNFPA /UNICEF (2014) Action for Adolescent Girls, Programme document, www.UNFPA AAG programme document_25july2014-pdf.

UNFPA(2013) "Motherhood in Childhood: Facing the challenge of adolescent pregnancy", N.Y.

UNICEF (2005), Early MarriageA Harmful Traditional Practice, A Statistical Exploration, www.unicef.org/sowc06/pdfs/Early_Marriage_12.lo.pdf.

UNICEF (2012) The population of Children and Young People Case Analysis in Turkey, www.unicef.org.tr/files/bilgimerkezi/doc/sitan-eng-2011.pdf.

UNICEF (2014) La Situation Des Enfants Dans Le Monde 2014, En Chiffres,www.unicef.org/french/sowc2014/numbers.

UNICEF, (2012b) Turkey Country Report, All Children In School By 2015, Ankara.

UNICEF-Turkey (2012a) Terms Of Reference (Tor) Social Policy Short Term National Consultancy, www.Unicef.Org.Tr/Vera/App/Var/Files/T/O/Tor-Chid-Well-Being-Document

Union of Turkish Bar Associations (2014), Child Bride Semposium 24.01.2014, www.barobirlik.org.tr/Detay.aspx?|D=22651

UNIVERSITY DICLE AND DIYARBAKIR MUNICIPALITY ( 2012), Results of the Research of Early marriages, Diyarbakır.

UNIVERSITY HACETTEPE (2009), Turkey 2008 Population and Health Survey, www.hips.hacettepe.edu.tr/eng/tdhs08/TDHS-2008_Main_Report.pdf.

UNIVERSITY HACETTEPE,(2014),Turkey 2013 Demographic and Health Survey, Ankara www.hips.hacettepe.edu.tr/TDHS_2013_main.report.pdf.

VÉRǴTÉ, E. (2003) La parentalité commence avant la naissance, La Santé de l'Homme, n 367 , septembre-octobre.

WHO-World Health Organization (2006), Pregnant adolescents: Delivering on global promices of hope. Geneva, Switzerland: WHO Document Production Services.

ZOROĞLU, S.,TÜZÜN Ü., ġAR V.ÖZTÜRK, M., and all.(2001) The possible consequences of childhood abuse and neglect, Anadolu Psychiatrie Journal 2001; 2(2).

Note : Turkish Oral prensentation in VII. European Conference on Social and Behavioral Sciences, Bucharest, Romania, June 11-13, 2015 